\title{
A TÖBBLERAKATOS IDŐABLAKOS JÁRATSZERVEZÉSI FELADAT MATEMATIKAI ÉS ONTOLÓGIAI MODELLJE
}

\author{
Agárdi Anita \\ egyetemi tanársegéd, Miskolci Egyetem, Informatikai Intézet, Általános Informatikai Intézeti Tanszék \\ 3515 Miskolc, Miskolc-Egyetemváros, e-mail: agardianita@iit.uni-miskolc.hu
}

\begin{abstract}
Absztrakt
A cikkben a többlerakatos, időablakos járatszervezési feladat matematikai és ontológiai modelljét mutatom be. A járatszervezés egy logiszikai feladat, mely során adott poziciójú lerakatból a jármüvek kiszállitják az árukat a vásárlóknak. A cél legtöbbször a megtett út minimalizálása. Az ontológiát arra használják, hogy tudást reprezentáljanak bizonyos témakörben. Az ontológia valamely témakör fogalmait, és a köztük lévö kapcsolatokat írja le. A célja nem csak az információ ember számára történö leírása, hanem a számitógépi feldolgozás is. A cikkben a Protége nyill forráskódú ontológiai szerkesztövel létrehozott modellt mutatom be.
\end{abstract}

Kulcsszavak: járatszervezési feladat, matematikai modell, ontológia

\begin{abstract}
In this article the mathematical and ontology model of the Multi-Depot Vehicle Routig Problem with Time Windows (MDVRPTW) is introduced. The Vehicle Routing Problem is a logistical problem, where vehicles deliver products from the depot to the customers. The objective function in most of the time is the minimization of the length of the route. Ontology is used to represent knowledge on a particular subject. Ontology describes the concepts of a topic and the relationships between them. Its purpose is not only to describe information to humans, but also to process it by computer. In this article, a model created by the Protége open source ontology editor is presented.
\end{abstract}

Keywords: vehicle routing problem, mathematical model, ontology

\section{Bevezetés}

A logisztika egyik fontos feladata a megfelelő áru megfelelő időpontban történő, költséghatékony szállítása. A logisztika területén belül egy fontos feladat a járatszervezés, amely üzemen belüli vagy üzemen kívüli szállítási folyamatokat, vagy egy teljes ellátási láncot is modellezhet. A járatszervezési feladatnak számos típusa alakult ki az évek során a folyton változó ipari igényekhez alkalmazkodva. A klasszikus járatszervezés esetén egy adott pozíciójú lerakatból szállítjuk ki az árut a vásárlóknak. A feladat megoldását több kritérium is nehezíti. Adott a jármüvek száma, azok kapacitáskorlátja, a vásárlók áruigényei. A jármủvek a lerakatból kiindulva kiszállítják az egyes vásárlóknak az árut, majd viszszatérnek a lerakatba. Minden vásárló áruigényét ki kell szolgálni, és figyelembe kell venni a jármüvek kapacitáskorlátját. A cél legtöbbször a jármüvek által megtett út minimalizálása. A továbbiakban a járatszervezési feladat néhány típusát, korlátozási tényezőjét fogom bemutatni. A legegyszerübb járatszervezési feladat az utazó ügynök probléma (Traveling Salesman Problem) [1], ahol minden csomópontot egyetlen jármü látogat meg úgy, hogy egy körutat tesz meg a jármü. A többlerakatos járatszervezés (Multi-Depot Vehicle Routing Problem) [2] esetén több lerakat pozíciója adott, a jármüvek egy- 
egy lerakatból indulhatnak ki. Az időablakos járatszervezés (Vehicle Routing Problem with Time Window) [3] esetén a meglátogatandó vásárlókhoz adott egy időablak, azaz egy időintervallum, amin belül ki kell szolgálni a fellépő áruigényt. A nyílt utas járatszervezés (Open Route Vehicle Routing Problem) [4] a járatszervezés egy olyan típusa, ahol a járművek a lerakatból indulnak ki, de a vásárlók meglátogatása után nem térnek vissza a lerakatba. A lerakatok közti út (Vehicle Routing with InterDepot Route) [5] azt jelenti, hogy a jármüvek bármely lerakatba visszatérhetnek a vásárlók meglátogatása után. A fö- és allerakatos járatszervezés (Two-Echelon Vehicle Routing Problem) [6] esetén az árut a lerakatból elsőként köztes helyekre (allerakatokba azaz satellitekbe) szállítjuk, majd innen szállítjuk ki a vásárlóknak. A járatszervezés egyik leggyakrabban alkalmazott célfüggvénye a megtett út minimalizálása, de egyéb célfüggvényeket is alkalmaztak már a szerzők, például az üzemanyag felhasználás minimalizálása [7].

A logisztikai összetett folyamatok vizsgálatánál nagy segítséget jelenthet egy egységes tudásbázis megléte, amely információkat adhat a szereplők, a megkötések főbb paramétereiről. Az egységes tudásbázis leggyakrabban alkalmazott eszköze az ontológia [8-9], amely lehetőséget ad a domain specifikus és általános szabályok, tulajdonságok leírására.

Jelen cikkben, a többlerakatos, időablakos járatszervezési feladathoz (Multi-Depot Vehicle Routing Problem with Time Window) [10] tartozó matematikai modellt és az ontológiai leírást ismertetem.

\section{A többlerakatos, időablakos járatszervezési feladat matematikai modellje}

Ebben a fejezetben a többlerakatos járatszervezési feladat matematikai modelljét mutatom be a [11] cikk alapján. A kiválasztott feladat során adott a lerakatok pozíciója, a jármüvek száma, kapacitáskorlátjai. Adottak a vásárlók pozíciói, áruigényei, és időablakai is. A jármüvek a lerakatból kiindulva meglátogatják a vásárlókat, majd visszatérnek a lerakatba. A jármüvek nem léphetik túl a kapacitáskorlátjukat, és minden vásárló igényét ki kell szolgálni. A cél a megtett út minimalizálása.

$\mathrm{Az}$ 1. ábra a feladatot szemlélteti. Az ábrán $C 1, \ldots, C 9$ jelöli az egyes vásárlókat, $D 1$ és $D 2$ a lerakatokat. A $D$ jelöli az egyes vásárlók áruigényét, a $T W$ pedig az időablakot.

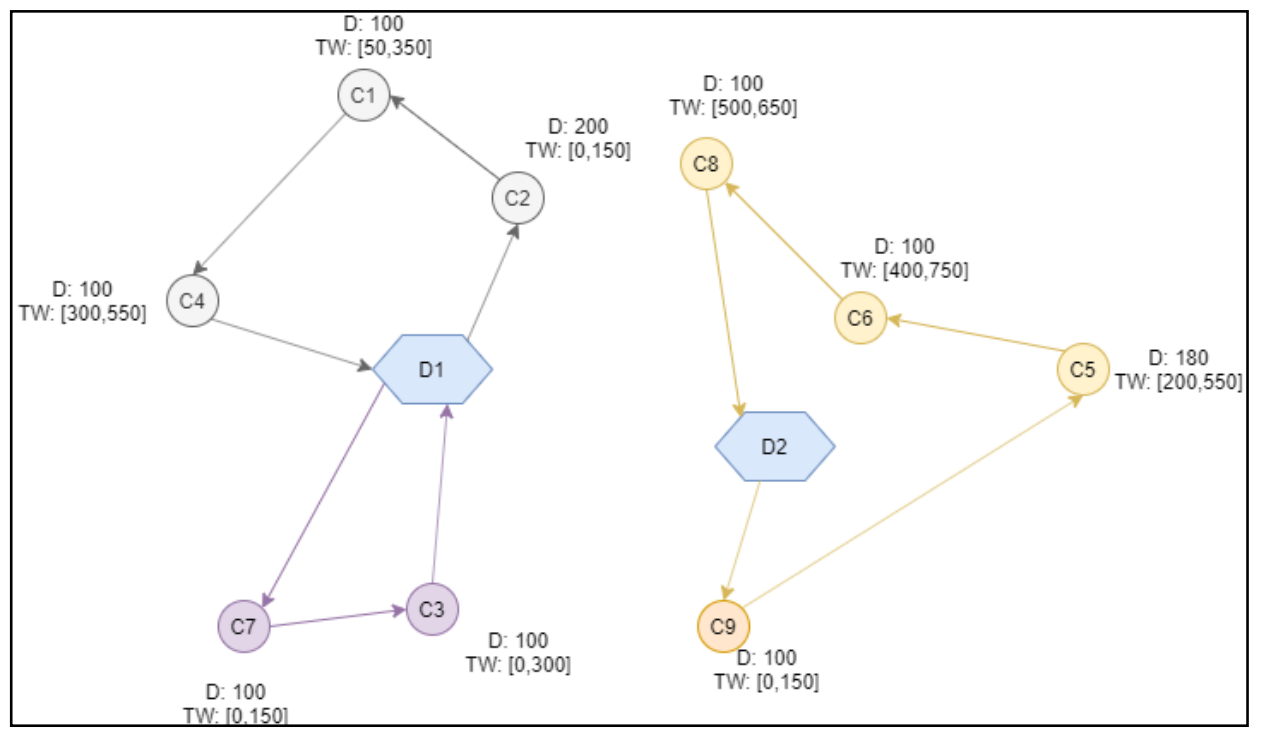

1. ábra. A többlerakatos, idöablakos járatszervezési feladat 
1. táblázat. A matematikai modellben elöforduló jelölések és jelentésük

\begin{tabular}{|c|c|}
\hline Jelölés & Jelentés \\
\hline$i, j$ & vásárló index \\
\hline$k$ & jármü index \\
\hline$l$ & lerakat index \\
\hline$C=\left\{c_{1}, c_{2}, \ldots, c_{n_{\text {customer }}}\right\}$ & vásárlók halmaza \\
\hline$D=\left\{d_{1}, d_{2}, \ldots, d_{n_{\text {depot }}}\right\}$ & lerakatok halmaza \\
\hline$V=\left\{v_{1}, v_{2}, \ldots, v_{n_{\text {vehicle }}}\right\}$ & járművek halmaza \\
\hline$C V=\left\{c v_{1}, c v_{2}, \ldots, c v_{n_{\text {vehicle }}}\right\}$ & jármüvek kapacitáskorlátjai \\
\hline$P D=\left\{p d_{1}, p d_{2}, \ldots, p d_{n_{\text {customer }}}\right\}$ & a vásárlók áruigényei \\
\hline$T W=\left\{t w_{1}, t w_{2}, \ldots, t w_{n_{\text {customer }}}\right\}$ & $\begin{array}{c}\text { a vásárlók időablakai, ahol } t w_{i}=\left[a_{i}, b_{i}\right] \text {, tehát a } \\
\text { legkorábbi és legkésőbbi kiszolgálás időpontja }\end{array}$ \\
\hline$y$ & a vásárlóhoz érkezés időpontja \\
\hline$x$ & döntési változó \\
\hline$M$ & pozitív nagy konstans \\
\hline$Z$ & célfüggvény \\
\hline
\end{tabular}

A döntési változó értéke 1 , ha a $k$. jármü az 1 . lerakatból indul ki, és az $i$. vásárló meglátogatása után közvetlenül a $j$. vásárlót látogatja meg, egyébként 0 .

A célfüggvény, melyet minimalizálunk:

$$
\mathrm{x}_{\mathrm{ij}}^{\mathrm{kl}} \in\{0,1\}
$$

$$
Z=\sum_{\mathrm{i}=1}^{n_{\text {customer }}} \sum_{\mathrm{j}=1}^{n_{\text {customer }}} \sum_{\mathrm{k}=1}^{n_{\text {vehicle }}} \sum_{\mathrm{l}=1}^{n_{\text {depot }}} \mathrm{d}_{\mathrm{ij}} \mathrm{x}_{\mathrm{ij}}^{\mathrm{kl}}
$$

1. korlát: egy vásárlót pontosan egyszer kell meglátogatni:

$$
\begin{array}{ll}
\sum_{\mathrm{i}=1}^{n_{\text {customer }}} \sum_{\mathrm{k}=1}^{n_{\text {vehicle }}} \sum_{\mathrm{l} \text { depot }}^{n_{\text {dept }}} \mathrm{x}_{\mathrm{ij}}^{\mathrm{kl}}=1 & \forall \mathrm{j} \in \mathrm{C} \\
\sum_{\mathrm{j}=1}^{n_{\text {customer }}} \sum_{\mathrm{k}=1}^{n_{\text {vehicle }}} \sum_{\mathrm{l}=1}^{n_{\text {depot }}} \mathrm{x}_{\mathrm{ij}}^{\mathrm{kl}}=1 \quad \forall \mathrm{j} \in \mathrm{C}
\end{array}
$$

2. Korlát: a jármúvek a vásárlók meglátogatása után abba a lerakatba érkeznek vissza, ahonnan elindultak:

$$
\begin{aligned}
& \sum_{\mathrm{j}=1}^{n_{\text {customer }}} \mathrm{x}_{\mathrm{ij}}^{\mathrm{kl}} \leq 1 \quad \forall \mathrm{k} \in \mathrm{V}, \forall \mathrm{i} \in \mathrm{C}, \forall \mathrm{l} \in \mathrm{D} \\
& \sum_{\mathrm{i}=1}^{n_{\text {customer }}} \mathrm{x}_{\mathrm{ij}}^{\mathrm{kl}} \leq 1 \quad \forall \mathrm{k} \in \mathrm{V}, \forall \mathrm{i} \in \mathrm{C}, \forall \mathrm{l} \in \mathrm{D}
\end{aligned}
$$

3. Korlát: útvonal folytonosság:

$$
\sum_{\mathrm{i}=1}^{n_{\text {customer }}} \mathrm{x}_{\mathrm{ij}}^{\mathrm{kl}}=\sum_{\mathrm{j}=1}^{n_{\text {customer }}} \mathrm{x}_{\mathrm{ij}}^{\mathrm{kl}} \forall \mathrm{k} \in \mathrm{V}, \forall \mathrm{i}, \mathrm{j} \in \mathrm{C}, \forall \mathrm{l} \in \mathrm{D}
$$

4. Korlát: időablak:

$$
\mathrm{a}_{\mathrm{i}} \leq \mathrm{y}_{\mathrm{i}}^{\mathrm{kl}} \leq \mathrm{b}_{\mathrm{i}} \forall \mathrm{k} \in \mathrm{V}, \forall \mathrm{i} \in \mathrm{C}, \forall \mathrm{l} \in \mathrm{D}
$$

5. Korlát: alkörút elimináció:

$$
y_{i}^{k l}-y_{j}^{k l} \leq M\left(1-x_{i j}^{k l}\right) \forall k \in V, \forall i, j \in C, \forall l \in D
$$

6. korlát: jármü kapacitáskorlátja:

$$
\sum_{\mathrm{j}=1}^{n_{\text {customer }}} p d_{j} \mathrm{x}_{\mathrm{ij}}^{\mathrm{kl}} \leq \mathrm{c}_{\mathrm{k}} \forall \mathrm{k} \in \mathrm{V}, \forall \mathrm{l} \in \mathrm{D}, \forall \mathrm{i} \in \mathrm{C}
$$




\section{A többlerakatos, időablakos járatszervezési feladat ontológiai modellje}

Az ontológia a szakterületek tudásábrázolására alkalmas, amely a témakör fogalmait és köztük lévő kapcsolatokat ábrázolja. Az ontológia építőelemei osztályok, az osztályok közti kapcsolatok, és az osztályok tulajdonságai. [12] Az ontológiák leírására leríró nyelveket használunk, ilyen leíró nyelv az OWL [13] is. A kutatásomban a Protége [14] ontológiai szerkesztővel alkottam meg a járatszervezési feladat ontológiai modelljét. Itt az osztályokat (Classes), skalár értékü tulajdonságokat (Datatype properties), az objektum értékủ tulajdonságokat (Object properties), és egyedeket (Entities) definiálhatunk.

Az osztályok (Classes) a témakör föbb fogalmait szimbolizálják. Az osztályok egyedek halmazait tartalmazzák. OWL-ben a Thing osztály minden osztály öse. Az osztályok rendelkezhetnek skalár értékủ tulajdonsággal (Datatype properties). Az objektum értékủ tulajdonságok (Object properties) pedig kettő vagy több osztályt kapcsolnak össze, tehát kettő vagy több egyed közti kapcsolatot írnak le. Például a hasId egy adatttag property (Datatype property), mert például a jármünek egy xsd:int típusú azonosítója van, de a hasTimeWindow egy objektum property (Object property), mert egy vásárlót és időablakot köt össze.

A 2. ábra az többlerakatos járatszervezés osztályait (Classes) mutatja. A Route osztály az útvonalat, a Solution a megoldást, a TimeWindow az időablakot, a Coordinate a koordinátát, a Vehicle a jármüvet, a Depot a lerakatot, a Customer a vásárlót jelenti.

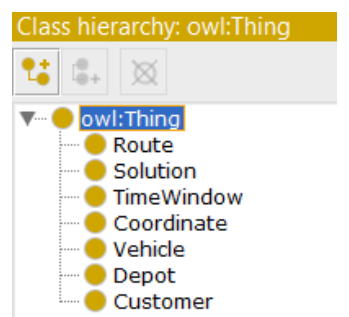

2. ábra. Osztályok (Classes)

A 3. ábra a skalár értékü tulajdonságokat (Datatype Properties) szemlélteti. A route_CustomerOrder a vásárlók sorrendjét mutatja az útvonalban, a timeWindow_latest és timeWindow_earliest az időablak intervallumai, a coordinate_y és coordinate_x az $x$ és $y$ koordinátákat, a vehicle_capacity a jármü kapacitáskorlátját, a vehicle_id a jármü azonosítóját, a depot_id a lerakat azonosítóját, a customer_id a vásárló azonosítóját jelenti.

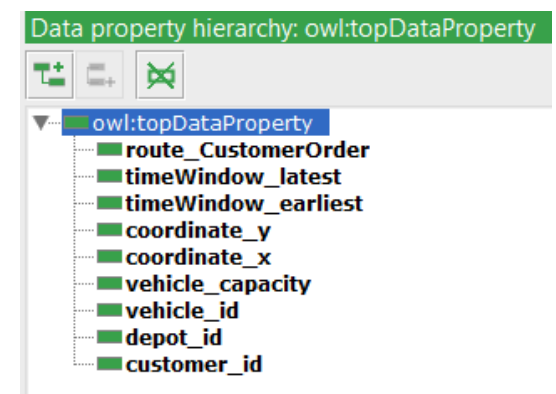

3. ábra. Adattag propertik (Data Properties) 
A 4. ábrán az objektum értékủ tulajdonságokat (Object Properties) láthatjuk. A route_hasCustomers egy Route és Customer osztályt kapcsol össze, ezen vásárlók tartoznak egy körútba. A route_hasDepot a Route és Depot osztályt kapcsolja össze, azaz egy körút lerakatát határozza meg. A route_hasVehicle egy Route és Vehicle osztályt kapcsol össze, azt a jármüvet határozza meg, amivel ami az adott körutat megteszi.

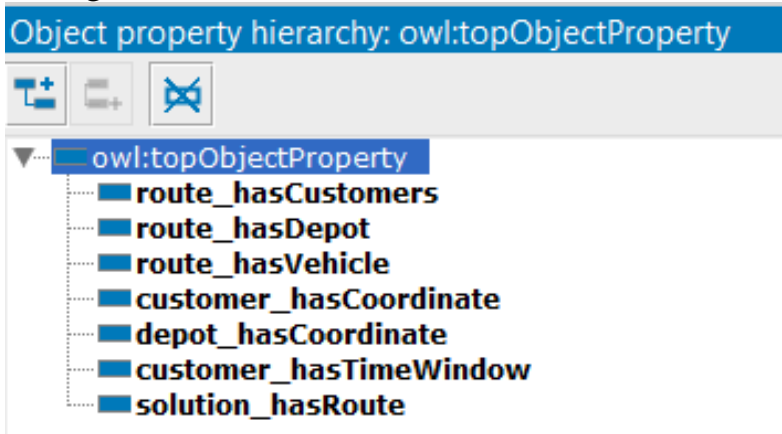

4. ábra. Objektum propertik (Object Properties)

Az 5. ábra az elkészült ontológiát az OWLViz [15] megjelenítővel mutatja. Itt láthatjuk az egyes osztályok kapcsolatát.

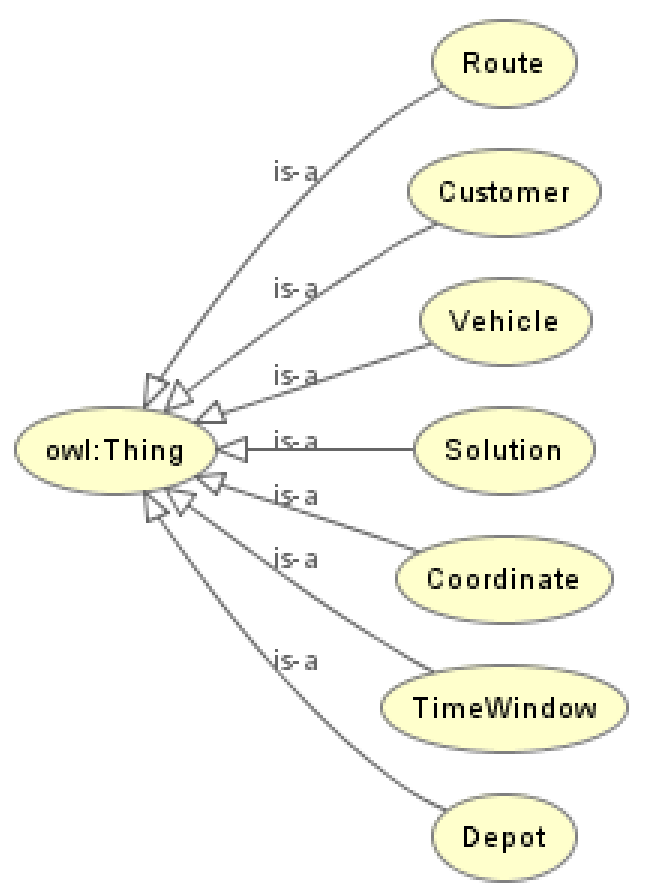

5. ábra. OWLViz ábrázolás 
A VOWL [16] szintén az ontológiai vizualizációt szolgálja, de ez egy gráfban ábrázolja az ontológiát. Itt láthatjuk az egyes osztályokat (Class) az osztályok skalár és objektum értékủ tulajdonságait, tehát a teljes rendszert. Hátránya, hogy nagyobb ontológiáknál a teljes rendszer egy „kusza” gráf.

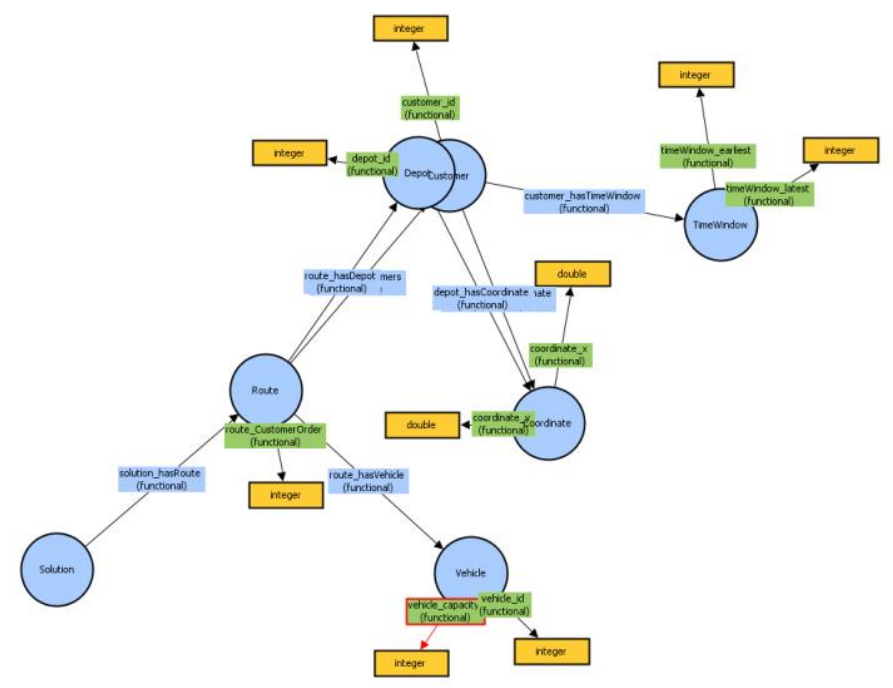

6. ábra. VOWL ábrázolás

Az OntoGraph [17] szintén az ontológiai vizualizációját támogatja. A 7. ábra mutatja az elkészült vizualizációt.

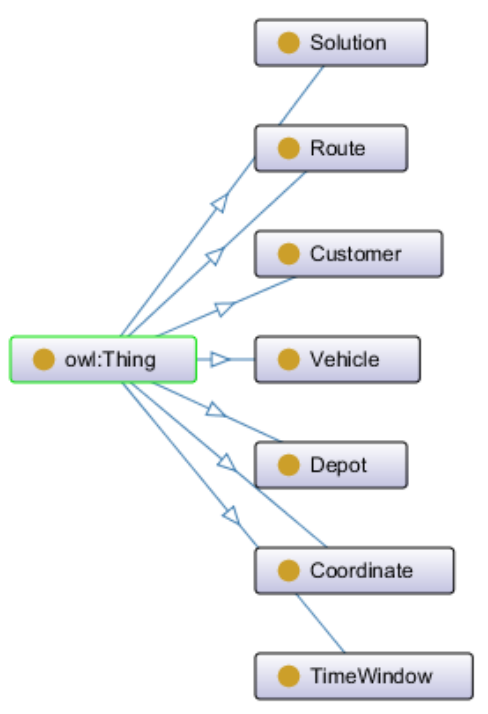

7. ábra. OntoGraf ábrázolás

A létrehozott modell segítségével megfogalmazhatóak az adott feladathoz tartozó megkötések, általános szabályok. Emellett az ontológia alkalmas a rendszer konzisztenciájának ellenőrzésére is. 


\section{4. Összefoglalás}

A cikkben bemutattam a járatszervezési feladatot, majd a többlerakatos, időablakos járatszervezési feladat matematikai és ontológiai modelljét. Az ontológiai modell Protége szoftverrel készült, vizualizálásra az OWLViz, a VOWL és az OntoGraf vizualizációs eszközöket használtam.

\section{Köszönetnyilvánítás}

A cikkben ismertetett kutató munka az EFOP-3.6.1-16-2016-00011 jelű „Fiatalodó és Megújuló Egyetem - Innovatív Tudásváros - a Miskolci Egyetem intelligens szakosodást szolgáló intézményi fejlesztése" projekt részeként - a Széchenyi 2020 keretében - az Európai Unió támogatásával, az Európai Szociális Alap társfinanszírozásával valósul meg.

\section{Irodalom}

[1] Kovács, L., Iantovics, L., \& Iakovidis, D.: IntraClusTSP-An Incremental Intra-Cluster Refinement Heuristic Algorithm for Symmetric Travelling Salesman Problem. Symmetry, 10(12), 2018, 663. https://doi.org/10.3390/sym10120663

[2] Renaud, J., Laporte, G., \& Boctor, F. F.: A tabu search heuristic for the multi-depot vehicle routing problem. Computers \& Operations Research, 23(3), 1996, 229-235. https://doi.org/10.1016/0305-0548(95)O0026-P

[3] Desrochers, M., Desrosiers, J., \& Solomon, M.: A new optimization algorithm for the vehicle routing problem with time windows. Operations research, 40(2), 1992, 342-354. https://doi.org/10.1287/opre.40.2.342

[4] Li, F., Golden, B., \& Wasil, E.: The open vehicle routing problem: Algorithms, large-scale test problems, and computational results. Computers \& operations research, 34(10), 2007, 2918 2930. https://doi.org/10.1016/j.cor.2005.11.018

[5] Crevier, B., Cordeau, J. F., \& Laporte, G.: The multi-depot vehicle routing problem with interdepot routes. European Journal of Operational Research, 176(2), 2007, 756-773. https://doi.org/10.1016/j.ejor.2005.08.015

[6] Perboli, G., Tadei, R., \& Vigo, D.: The two-echelon capacitated vehicle routing problem: Models and math-based heuristics. Transportation Science, 45(3), 2011, 364-380. https://doi.org/10.1287/trsc.1110.0368

[7] Kuo, Y.: Using simulated annealing to minimize fuel consumption for the time-dependent vehicle routing problem. Computers \& Industrial Engineering, 59(1), 2010, 157-165. https://doi.org/10.1016/j.cie.2010.03.012

[8] Kovács, L., Varga, E. B., \& Balla, T.: Efficiency analysis of ontology servers. In 2018 19th International Carpathian Control Conference (ICCC), 2018, 353-358. https://doi.org/10.1109/CarpathianCC.2018.8399655

[9] Kovács, L., \& Varga, E. B.: Ontológia-alapú nyelvtantanuló rendszer nyelvtan-modellje. A Magyar Tudomány Hete 2008 "A tudomány az élhető Földért" konferenciasorozat, 2008, 219-226.

[10] Bae, H., \& Moon, I.: Multi-depot vehicle routing problem with time windows considering delivery and installation vehicles. Applied Mathematical Modelling, 40(13-14), 2016, 65366549. https://doi.org/10.1016/j.apm.2016.01.059 
[11] Ombuki, B., Ross, B. J., \& Hanshar, F.: Multi-Objective Genetic Algorithms for Vehicle Routing Problem with Time Windows. Applied Intelligence, 24(1), 2006, 17-30. https://doi.org/10.1007/s10489-006-6926-Z

[12] Gruber, T.: Encyclopedia of Database Systems - Ontology, 2009, 1963-1965. https://doi.org/10.1007/978-0-387-39940-9_1318

[13] OWL: https://www.w3.org/OWL/ (Hozzáférés dátuma: 2020. 04. 24.)

[14] Protége: https://protege.stanford.edu/ (Hozzáférés dátuma: 2020. 01. 05.)

[15] OWLViz: https://github.com/protegeproject/owlviz (Hozzáférés dátuma: 2020. 01. 05.)

[16] VOWL: http://vowl.visualdataweb.org/ (Hozzáférés dátuma: 2020. 01. 05.)

[17] OntoGraph: https://github.com/NinePts/OntoGraph (Hozzáférés dátuma: 2020. 01. 05.) 